\title{
DESTRUCTIVENESS OF PROFITS AND OUTLAYS ASSOCIATED WITH OPERATION OF OFFSHORE WIND ELECTRIC POWER PLANT. PART 1 : IDENTIFICATION OF A MODEL AND ITS COMPONENTS
}

\author{
Andrzej Tomporowski ${ }^{1}$ \\ Józef Flizikowski1 \\ Weronika Kruszelnicka ${ }^{1}$ \\ Izabela Piasecka ${ }^{1}$ \\ Robert Kasner ${ }^{1}$ \\ Adam Mroziński ${ }^{1}$ \\ Stepan Kovalyshyn ${ }^{2}$ \\ ${ }^{1}$ University of Science and Technology in Bydgoszcz, Poland \\ ${ }^{2}$ Lviv National Agrarian University, Ukraine
}

\begin{abstract}
This paper describes identification and components of destructiveness of energy, economic and ecologic profits and outlays during life cycle of offshore wind electric power plants as well as the most useful models for their design, assembly and use. There are characterized technical conditions (concepts, structures, processes) indispensable for increasing profits and/or decreasing energy, economic and ecological outlays on their operation as well as development prospects for global, European and domestic markets of offshore wind electric power industry. A preliminary analysis was performed for an impact of operators, processed objects, living and artificial environmental objects of a $2 M W$ wind electric power plant on possible increase of profits and decrease of outlays as a result of compensation of destructiveness of the system, environment and man.
\end{abstract}

Keywords: offshore wind electric power plants, energy, economic and ecological effectiveness, destructiveness

\section{INTRODUCTION}

Intelligent development of offshore power industry consists in knowledge of wind electric power engineering, postulated states and innovation in technical conditions. As results from the EU document titled: Offshore wind energy: actions necessary for realization of energy policy aims in the period up to 2020 and over, $40 \%$ of energy production potential connected to the electric network comes from wind electric power industry. In Poland, an elementary important issue for development of offshore wind electric power industry is associated with possibility of connecting new installations to the Domestic Electric Power System, formation of own port and shipyard infrastructure as wel as a stable and effective support system for restorable energy sources [1, 10, 19, 21].
Barriers to progress in intelligent development of offshore wind electric power industry have been so far associated with energy, economic and ecological conditions as well as administrative and legal obstacles. Owing to the act on Polish sea regions and maritime administration, new conditions for location of offshore wind electric power installations in domestic sea regions came into effect in 2011. The area of Polish sea regions amounts to about 33 thousand $\mathrm{km}^{2}$. however the total area of sea waters officially assigned to be potentially available for developing offshore wind electric power industry reaches over $2.000 \mathrm{~km}^{2}$. In Poland, the first planned investment into an offshore wind electric power farm has to have the rated power of about $100 \mathrm{MW}[2,4,8,19,21]$. 
The main aim of the presented work is to elaborate and verify a rational reasoning consisted in a logical association of destructiveness with decreasing profits from and increasing outlays on operation of offshore wind electric power plants, as well as methods for investigation of such relations for : ergonomicity of operators, functionality of processed objects, friendliness for natural environment and rate of wear in artificial environmental objects - working units of wind electric power plant.

\section{DESIGN MODEL}

Statistical mathematical design models for offshore systems may be developed by means of one of the following methods:

1. Theoretical analysis of systems conducted on the basis of detail knowledge of phenomena occurring in the systems. A very high complexity of most of the systems and incomplete knowledge of phenomena occurring in them result in that such method leads to a searched model only for a group of simple systems. Determination of such model dealing with profits, outlays, destruction and consequences of power processing would be a very complicated task.

2. Experimental analysis of systems, called identification. The identification consists in the verifying - on the basis of measurements of input quantities (technical conditions (Wt)) and output ones of the system (i.e. postulated states (SP)) conducted in the course of a program of experiments specially dedicated for this purpose - of an invented mathematical model of a definite class, which would be capable of predicting, in a sufficiently exact way, output quantities of the identified system and offshore environment on the basis of knowledge of changeability of their input quantities.

In order to make the achieving of large profits and low outlays possible, i.e. reaching the main aim of this work, it was decided to identify - with the use of experimental analysis of systems - the profits and outlays and their components and to make an attempt to describing their relation with operational destructiveness of : operators, devices, living and artificial environmental objects, for selected raw materials, plastic and structural materials used for a wind electric power plant unit.

Technical conditions: The design process of the technical conditions $(\mathrm{Wt})$ for wind electric power plants intended for costal zone (Fig.1) consists first of all in creating grounds for social consent for the construction and destruction conditions as well as the aim of the undertaking in question, i.e. the postulated state (SP) of a higher energy, economic and ecological effectiveness throughout its life-cycle operation [3, $11,12,17,20,25]$.

Social consent depends on high profits, high effectiveness, low outlays and -generally - on a low destructiveness of operation of wind electric power plants. An offshore system will be here considered a set of the elements, $E_{1}, E_{2}, \ldots, E_{m}$ mutually connected in accordance with a definite concept, together with the relations between the elements, $R$, $R_{2}, \ldots, R_{m}$, while energy and information fluxes flow through the channels of the relations during all life cycle in compliance with respective operational plan.

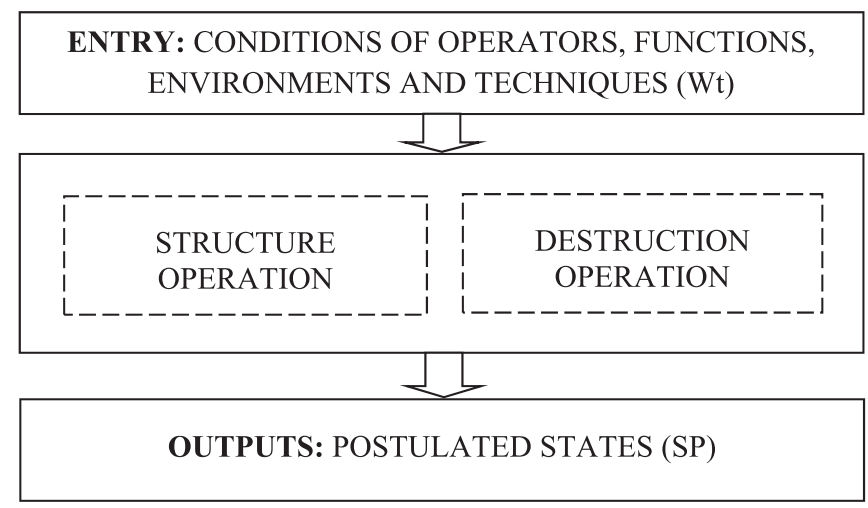

Fig. 1. Constructional and operational impact of the environment on the construction of a technical object (these authors' original elaboration)

The characteristics of the elements as well as their relations are functions of the life-cycle conditions $W$ and time $t$ taken as a variable independent of development of the system and the instant of the dynamic process $\Theta$. Moreover, the relations $R_{i}$ depend also on the control signals s:

The technical conditions (Wt), elements (E), relations (R), control signals (s) and operational time (t), i.e. $\mathrm{Wt}(\mathrm{E}, \mathrm{R}, \mathrm{s}, \mathrm{t})$, are equivalent to :

$$
\begin{aligned}
& E_{1}=E_{1}(\bar{W}, \Theta, t), \\
& E_{2}=E_{2}(\bar{W}, \Theta, t), \\
& E_{m}=E_{m}(\bar{W}, \Theta, t), \\
& R_{1}=R_{1}(W, s, \Theta, t), \\
& R_{2}=R_{2}(W, s, \Theta, t), \\
& R_{n}=R_{n}(W, s, \Theta, t) .
\end{aligned}
$$

1. Concepts of solution of technical means, ways of processing wind energy potentials;

2. Design features of the technical means such as : towers, machines, devices, process installations, control systems, information and logistic systems for energy processing;

3. Operations, process parameters, elements motion modes, wind parameters, product parameters and process system relations.

The technical conditions undergo a forming process and are changeable during life cycle of wind electric power plant, there are also changeable the outlays $(\mathrm{N})$, and the profits (K) and their relations, i.e. the effectivenesses (e) of the technological processes associated with the need formulation, designing, constructing, manufacturing, investing, using and 
liquidation, i.e. the life-cycle phases of power engineering objects (Fig. 2) [5, 26, 27]:

1. Formulation of needs $\left(\mathrm{N}_{\mathrm{f}-\mathrm{p}}, \mathrm{K}_{\mathrm{f}-\mathrm{p}}, \mathrm{e}_{\mathrm{f}-\mathrm{p}}\right)$,

2. Designing $\left(\mathrm{N}_{\mathrm{p}}, \mathrm{K}_{\mathrm{p}}, \mathrm{e}_{\mathrm{p}}\right)$,

3. Constructing $\left(\mathrm{N}_{\mathrm{k}}, \mathrm{K}_{\mathrm{k}}, \mathrm{e}_{\mathrm{k}}\right)$,

4. Manufacturing $\left(\mathrm{N}_{\mathrm{w}}, \mathrm{K}_{\mathrm{w}}, \mathrm{e}_{\mathrm{w}}\right)$,

5. Investing $\left(\mathrm{N}_{\mathrm{in}}, \mathrm{K}_{\mathrm{in}}, \mathrm{e}_{\mathrm{in}}\right)$,

6. Using, servicing, supplying $\left(\mathrm{N}_{\mathrm{u}-\mathrm{o}-\mathrm{z}}, \mathrm{K}_{\mathrm{u}-\mathrm{o}-\mathrm{z}}, \mathrm{e}_{\mathrm{u}-\mathrm{o}-\mathrm{z}}\right)$,

7. Post-service managing by recycling and/or storing $\left(\mathrm{N}_{\text {retskł }}, \mathrm{K}_{\text {re+skł }}, \mathrm{e}_{\text {re+skt }}\right)$.

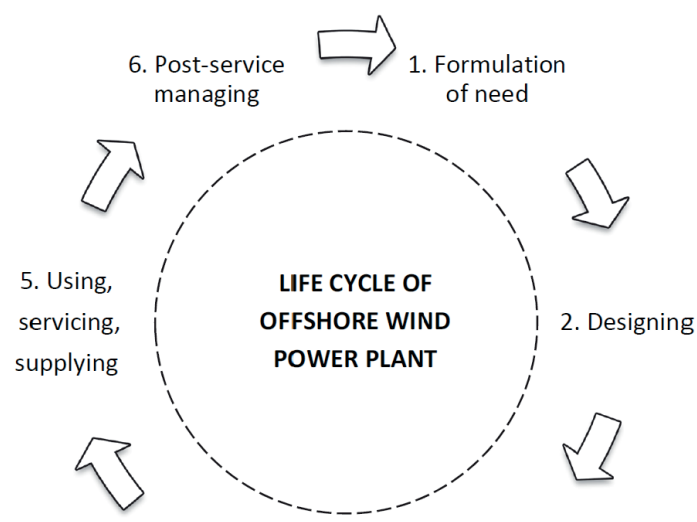

4. Manufacturing

3. Constructing

Fig. 2. Processes, life cycle and existence phases of technology of working units of offshore wind electric power plant (these authors' original elaboration)

Effectivenesses: the energy effectiveness $\mathbf{e}_{\text {en }}$, economic effectiveness $\boldsymbol{e}_{\text {eko }}$ and ecological one $\boldsymbol{e}_{\text {EKO }}$ depend on the one-nominal profits $\left(\boldsymbol{K}_{\text {en,eko,EKO}}\right)$ and outlays $\left(\boldsymbol{N}_{\text {en,eko,EKO}}\right)$, destructiveness $\left(\boldsymbol{D}_{\text {s-o-c }}\right)$ and operational time $\left(\boldsymbol{t}_{\boldsymbol{e}}\right)$ :

$$
\begin{aligned}
& S P\left(e_{e n, e k o=E K O}\right)_{z E W}=f\left(K_{e n, e k o, E K O}, N_{e n, e k o, E K O}, D_{s-0-c}, t\right)_{z E W} \\
& \left(K_{e n, e k o, E K O}, N_{e n, e k o, E K O}\right)_{z E W}=f\left(D_{s-o-c}, D_{o}, D_{\rho} D_{E k o}, D_{s}, t\right)
\end{aligned}
$$

where:

$\boldsymbol{S P}\left(\boldsymbol{e}_{\text {en,eko EKo }}\right)_{z E W}$ - aims, postulated states: energy, economical and ecological effectivenesses of operation of wind electric power plant and its units as well,

$\boldsymbol{e}_{\text {en,eko,EKo }}$ - energy, economic and ecological effectiveness of wind electric power plant operation in sea natural environment,

$K_{\text {en,eko,Еко }}$-energy, economic and ecological profits from wind electric power plant operation in sea natural environment,

$\boldsymbol{N}_{\text {en,eko,EKO }}$ - energy, economic and ecological outlays on wind electric power plant operation in sea natural environment,

$D_{s-o-c}$ - destructiveness of a system, environment and man,

$D_{o}$ - "deergonomicity" ( deergonomic features ) of technical system operators and the environment,

$D_{f}-$ „defunctionality” ( defunctional features ) of technical system's processing variables,

$D_{\text {Eko }}$ - „deecologicity” ( deecological features) of living environmental objects,

$D_{s}$ - „desozologicity” (desozological features) of artificial objects of system and/or environment,

$\boldsymbol{t}_{\boldsymbol{e}}$ - operational time.

During exploitation of resources the following items are gained for further utilization - usage $[6,9,13,15,28]$ :

- Natural deposits and industrial, knowledge and scientific assets;

- Potentials of natural environment and creative people (engineers).

The potentials achieved this way are subjected to further usage in the form of technical means, ways and states and their transformations $[14,16,23,29]$ for:

- Creating

- Using

- Servicing

- Wearing out, supplying

- Lquidation of machines and devices

- Post-service utilization of potentials of raw materials, and waste materials recycling, regeneration, storage or their complete consumption. Tab. 1 presents mathematical models belonging to the class of index effectiveness, which make it possible to predict suficiently exactly values of profits from and outlays on an identified offshore system and its environment on the basis of known values of their input quantities.

Tab.1: Models of profits, outlays and effectivenesses of the designing, manufacturing and using of an offshore wind electric power plant during its

\begin{tabular}{|c|c|c|}
\hline \multicolumn{3}{|c|}{ Models of profits, outlays and effectivenesses in the life cycle of an offshore wind power plant } \\
\hline Index & Relation & No. \\
\hline Energy profit & $\Delta E_{E n}=K_{f-p}+K_{p}+K_{k}+K_{w}+K_{i n}+K_{u-o-z}+K_{r e+s k l}$ & (3) \\
\hline Energy outlays & $N_{E n}=N_{f-p}+N_{p}+N_{k}+N_{w}+N_{i n}+N_{u-o-z}+N_{r e+s k l}$ & $(4)$ \\
\hline Economic profit & $\Delta E_{E k o}=K_{f-p}+K_{p}+K_{k}+K_{w}+K_{i n}+K_{u-0-z}+K_{r e+s k l}$ & $(5)$ \\
\hline $\begin{array}{l}\text { Economic } \\
\text { outlays }\end{array}$ & $N_{E k o}=N_{f-p}+N_{p}+N_{k}+N_{w}+N_{i n}+N_{u-o-z}+N_{r e+s k l}$ & $(6)$ \\
\hline Ecological profit & $\Delta E_{E K O}=K_{f-p}+K_{p}+K_{k}+K_{w}+K_{i n}+K_{u-o-z}+K_{r e+s k l}$ & $(7)$ \\
\hline $\begin{array}{l}\text { Ecological } \\
\text { outlays }\end{array}$ & $N_{E K O}=N_{f-p}+N_{p}+N_{k}+N_{w}+N_{i n}+N_{u-o-z}+N_{r e+s k t}$ & $(8)$ \\
\hline Energy & $e_{E n}=f\left(D_{o-s-c}\right)=\frac{\Delta E_{E n}}{N_{E n}}$ & (9a) \\
\hline effecitiveness & $e_{E n}=\frac{\Delta E_{E n}}{N_{E n}}=\frac{K_{f-p}+K_{p}+K_{k}+K_{w}+K_{i n}+K_{u-0-z}+K_{r e+s k t}}{N_{f-p}+N_{p}+N_{k}+N_{w}+N_{i n}+N_{u-o-z}+N_{r e+s k t}}$ & $(9 b)$ \\
\hline
\end{tabular}
life cycle 


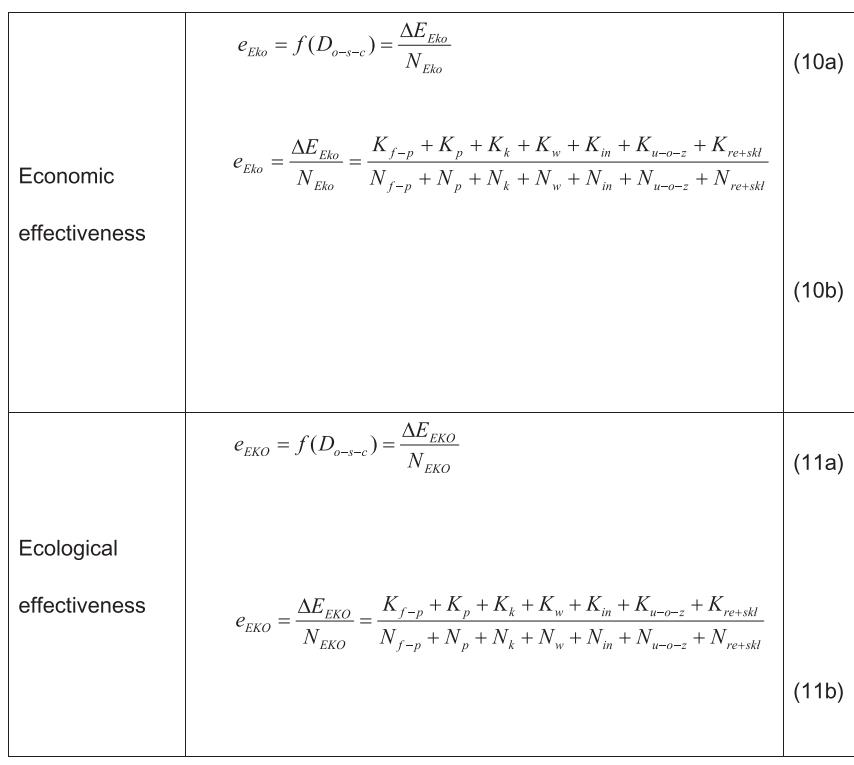

where in Eq. (3) through (11b) the following denotation is applied:

e - index of a kind of effectiveness ( energy, economic, ecological one),

$\mathrm{K}$ - profits ( energy, economic, ecological ones),

$\mathrm{N}$ - outlays ( energy, financial ones and those dealing with environmental resources),

$\Delta$ - increment of profits ( energy, economic, ecological ones),

For the selected models the following states (1-5) of the processed construction were assumed :

1. Stand-by, waiting and storing,

2. Idle run - without load,

3. Useful processing work,

4. Energy losses, dispersion and dissipation,

5. Repair, maintenance, regeneration and recycling.

Moreover, for processing, controlling, informing and logistic servicing, all the system construction units satisfy the criteria of :

1. optimum loading (Koo),

2. optimum structural material (Kot),

3. optimum stability (Kos),

4. optimum relations of interacting quantities (Kosw).

There was assumed a positive, constructional operation of the system supplemented with a negative, destructive action in the form of : errors, inaccuracies, non-usability of operators, machines, natural elements and instability of living and artificial objects of natural and technological environment.

Destructiveness. Destructive elements, relations and oversteeerings (Fig.3), in the frame of the „deergonomicity”, trigger features, inaccuracies, non-usability of operator during his work on the post ; similarly it happens in the "defunctionality” of machines, devices and installations of offshore wind electric power plant, or in the „deecologicity” - impetuous, destructive actions of sea natural environment and its resources, as well as in the "desozologicity" - destruction of the wind electric power plant construction and loss of its elements, wear of elements of its devices, sub-units and components [7, 18, 22, 24].
Fig. 3. Characteristics of system's action in operational processes of: operator, electric power plant, environment, machines, devices and installations (these authors' original elaboration)
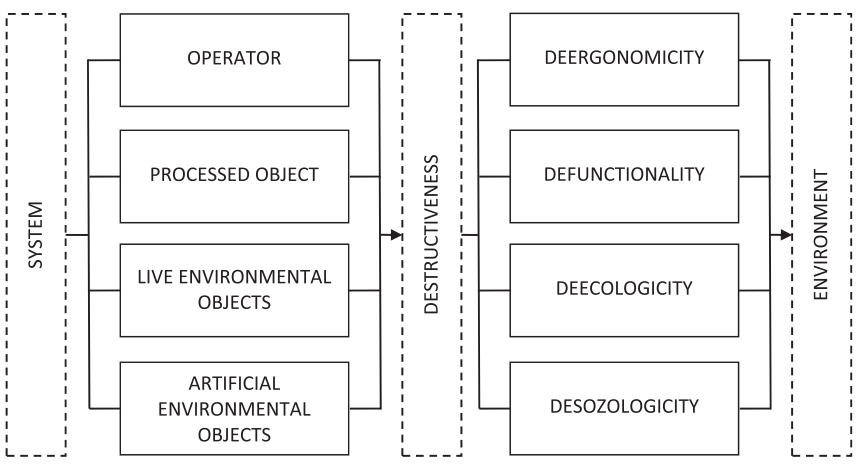

The initial point for defining detail characteristics which express system's destructiveness in relation to characteristic elements of its environment is the identifying of the elements by decomposing the environment into elements which are distinguished by specific relations between them and the system. Based on this criterion, there is possible to distinguish the following (Fig. 3):

- $\quad$ operators, i.e. persons which directly run the system or permanently stay in its surrounding,

- $\quad$ processed object, i.e. air, water and that part of the environment which is directly affected by the system according to its purpose,

- $\quad$ living environmental objects, i.e. natural objects present in the surrounding of offshore wind electric power plant,

- artificial environmental objects, i.e. technical infrastructure of the system as well as all man-made objects located in the surrounding of the system.

System's destructiveness indices. On the analogy of the effectiveness, destructiveness indices may serve as destructive hazard measures. Procedure of their forming is analogous to that for effectiveness indices and contains :

1. Determining the set of variables :

$$
X=\left\{X_{k} ; k=\overline{1, K}\right\}
$$

where:

$X_{1}=S$ - losses, $X_{2}=T$ - time, $X_{3}-G$ - object's characteristics, $X_{4}=N$ - outlays.

2. Determining the set of variables for each of the elements $A_{k}$ :

$$
X_{k}=\left\{X_{k l} ; i=\overline{1, l}\right\}
$$

3. Defining the variable:

$$
X_{k, l+1}=\sum_{l}^{1} X_{k l}
$$

4. Defining the quotients :

$$
p_{i j}^{k l}=\frac{X_{k i}}{X l j}
$$


where:

$$
k, l=l \ldots \ldots \ldots . . K, i, j=1 \ldots \ldots \ldots(I+1) .
$$

5. Organizing the indices by the indices $k, 1, i, j$ as well as arranging them into the framed block matrices :

$$
p^{k l}=\left[\begin{array}{l}
{\left[B^{k l}\right]\left[V^{k l}\right]} \\
{\left[H^{k l}\right]\left[\alpha^{k l}\right]}
\end{array}\right]
$$

where:

$\mathrm{a}^{\mathrm{kl}}$ - general indices, $\mathrm{V}^{\mathrm{kl}}, \mathrm{H}^{\mathrm{kl}}$ - principal indices, $\mathrm{B}^{\mathrm{kl}}-$ detail indices, $\mathrm{p}-$ matrix of destructiveness indices $-p_{i j}^{k l}$

6. Detail examining the indices from the matrix $P^{k l}$ which expresses relations between the losses $S$ and the outlays $\mathrm{N}$. Type and number of detail destructiveness measures depend on a class of a system in question and its specificity.

\section{RESULTS AND DISCUSSION}

Fragmentary effectiveness. The achieved results for variables of the operational effectiveness model of profits gained from energy outlays are presented in Tab. 2, 3 and 4.

Tab. 2 Energy profits gained from operation of the wind electric power plant

\begin{tabular}{|c|c|c|c|c|c|c|c|c|c|c|c|c|}
\hline \multicolumn{13}{|c|}{ Energy profits for wind turbine } \\
\hline & Jan & 泀 & $\begin{array}{l}\text { 苞 } \\
\stackrel{\Xi}{\Sigma}\end{array}$ & 竞 & 㲾 & $\stackrel{\Xi}{\Xi}$ & $\underline{\Xi}$ & 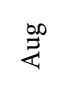 & 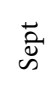 & $\overleftarrow{\breve{~}}$ & zo & ֻั \\
\hline$\stackrel{m}{\stackrel{n}{\sim}}$ & 538 & 304 & 586 & 412 & 327 & 250 & 254 & 276 & 381 & 520 & 498 & 650 \\
\hline$\underset{⿱ 亠}{\stackrel{H}{\sim}}$ & 588 & 548 & 448 & 360 & 457 & 272 & 274 & 264 & 326 & 327 & 387 & 591 \\
\hline$\frac{10}{\stackrel{1}{0}}$ & 739 & 400 & 531 & 548 & 321 & 242 & 325 & 362 & 377 & 392 & 551 & 730 \\
\hline
\end{tabular}
Vestas V90 in the years 2013-2015, [MWh] (acc. these authors' original work)

Tab. 3 Energy outlays on operation of the electric power station Vestas V90 in

\begin{tabular}{|c|c|c|c|c|c|c|c|c|c|c|c|c|}
\hline \multicolumn{13}{|c|}{ Energy outlays for wind turbine } \\
\hline & $\underset{\Xi}{\Xi}$ & 苞 & 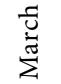 & 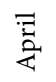 & 㲾 & $\stackrel{\Xi}{\Xi}$ & $\underline{\Xi}$ & $\stackrel{\infty}{=}$ & 苛 & 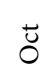 & $\begin{array}{l}\text { aे } \\
\text { z }\end{array}$ & $\ddot{\Xi}$ \\
\hline$\stackrel{m}{\stackrel{2}{\sim}}$ & 1,47 & 1,63 & 0,74 & 1,79 & 2,13 & 3,84 & 2,47 & 2,71 & 1,83 & 1,17 & 1,45 & 0,49 \\
\hline$\underset{\sim}{\stackrel{\sim}{\sim}}$ & 2,27 & 0,58 & 1,67 & 1,47 & 0,97 & 1,89 & 1,73 & 1,35 & 1,52 & 1,21 & 1,63 & 1,32 \\
\hline$\stackrel{n}{\stackrel{n}{0}}$ & 0,45 & 0,73 & 0,71 & 0,67 & 1,92 & 1,92 & 1,78 & 1,51 & 1,28 & 1,31 & 1,16 & 0,40 \\
\hline
\end{tabular}
the years 2013-2015, [MWh] ( acc. these authors' original work)
Tab. 4 Energy effectiveness of operation of the wind electric power plant Vestas V90 in the years 2013-2015, (acc. these authors' own work)

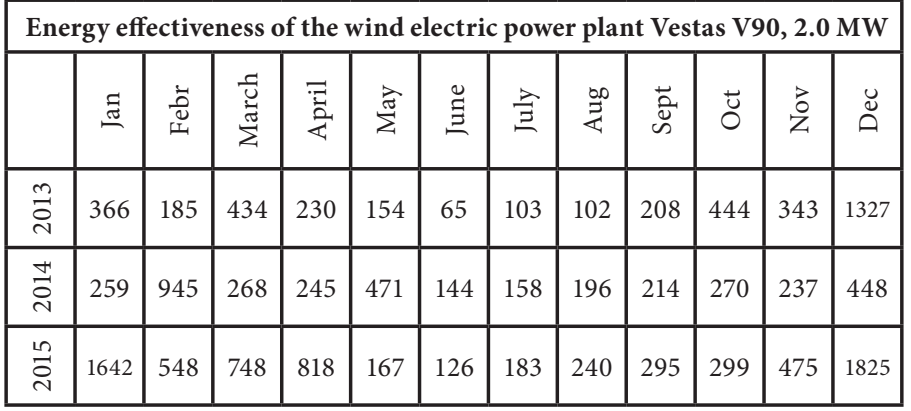

Tab. 5 shows values of one-year and three-year energy operational effectiveness of the wind electric power plant Vestas V90, according to the simplified relation (9b) covering mainly the usage (u), partly the servicing (o) and the supply $(\mathrm{z})$ :

$$
e_{E n u}=\frac{\Delta E_{E n u}}{N_{E n u}}=\frac{K_{u-o-z}}{N_{u-o-z}}
$$

Tab. 5 One-year and three-year energy effectiveness of operational phases of the electric power plant Vestas V90 in the years 2013-2015 (acc. these authors' original work)

Energy effectiveness of the electric power plant Vestas V90, 2.0 MW

\begin{tabular}{|c|c|c|}
\hline Year & One-year effectiveness & $\begin{array}{c}\text { Three-year } \\
\text { effectiveness }\end{array}$ \\
\hline 2013 & 331,10 & \multirow{2}{*}{4} \\
\cline { 1 - 2 } 2014 & 321,25 & \multirow{2}{*}{422,06} \\
\hline 2015 & 613,83 & \\
\hline
\end{tabular}

The mean one-year energy effectiveness of using, servicing and supplying phases reaches values from the interval $(321,25 ; 613,83)$, whereas for the 3 -year period the mean amounts to $e_{E n u}=422,06$. Such values are rather unavailable either in proffesional power industry or bioenergy activity in other areas of man's undertakings.

Life- cycle destruciveness. The best exemplification of the considerations on positive effects of construction and negative effects of destruction of a system is an analysis of offshore system's destructiveness. It results from specificity of the system itself, from its entirely specific environment in which all four distinguished elements are present. Since the offshore system, according to its definition, affects both constructively - the processed objects, acting as means for instrumentalization bioenergetic processes, and destructively - the operator, processed object as well as the natural and artificial surrounding objects which form its environment.

To specify the considerations, the wind electric power plant Vestas was taken into account as an example. Thus, there is possible to show close relations which occur between constructiveness of the system and its destructiveness when wind, water, soil, manmade and natural materials impact the object. The offshore specificity consists in that a constructive effect is 
reached by means of natural elements which are destructive by themselves. Let's assume that the impacts will be realized by the effects $U$ (constructive), losses $S$ (destructive) and outlays N. To simplify, let's assume that the impacts will be represented by a number of the points $\mathrm{Pt}$, according to the LCA procedure (Fig. 4 - rotor of wind electric power plant, Fig. 5 - $1 \mathrm{~kg}$ amount of man-made and natural materials and elements, Fig.6 - emissions of chemical compounds to atmosphere, water and soil).

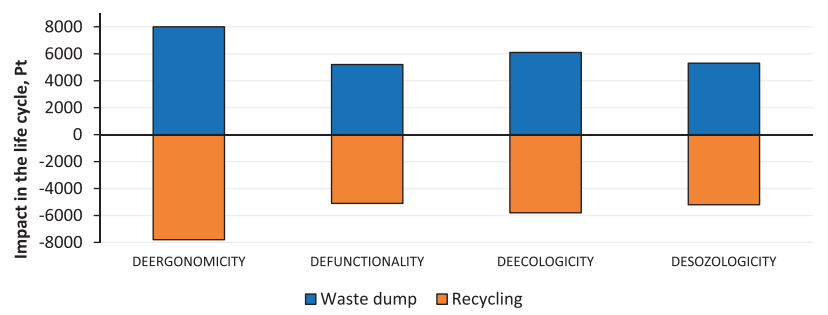

Fig.4. Life-cycle impact of the rotor representing a working unit of the wind electric power plant Vestas, for various kinds of its destructiveness related to models of post-service utilization by storing on waste dump or recycling (acc. these authors'original work)

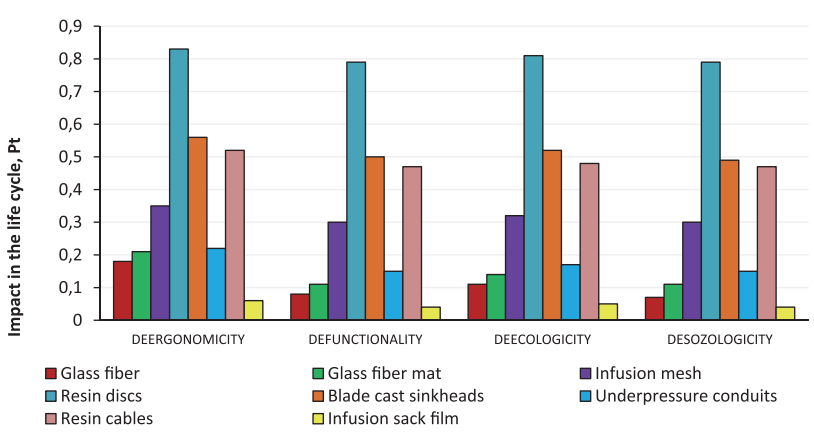

Fig.5. Life-cycle impact of $1 \mathrm{~kg}$ amount of man-made and natural materials and elements being post-service waste from the rotor blade of the wind electric power plant, related to various kinds of its destructiveness (acc. these authors' original work)
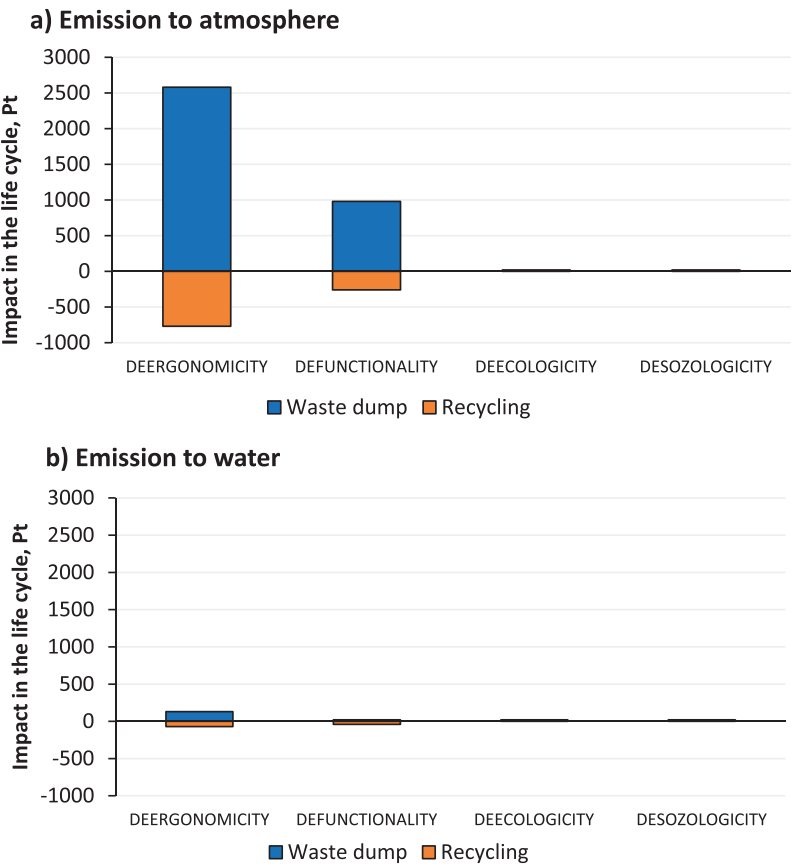

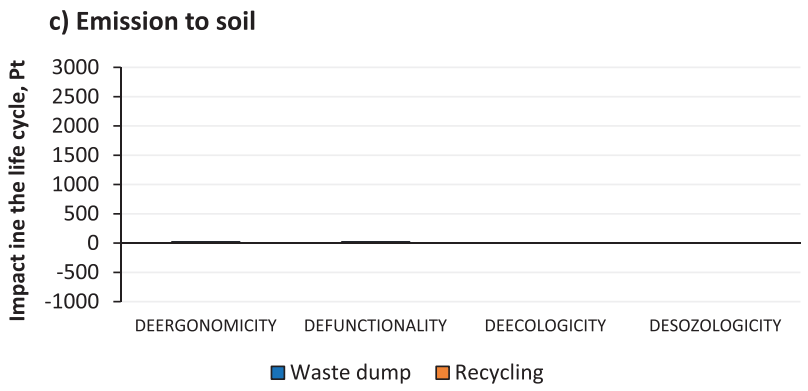

Fig.6. Life-cycle impact of the rotor representing a working unit of the wind electric power plant Vestas, for various kinds of its destructiveness related to emission: a) emission to atmosphere, $b$ ) emission to water, c) emission to soil (acc. these authors' original work)

\section{RECAPITULATION AND CONCLUSIONS}

The main aim of this work consisting in the working out and verifying of a rational relation between destructiveness and lowering profits from and increasing outlays on operation of offshore wind electric power plants for particular phases of their lives in the range of energy, economics and ecology, was reached.

There were tested the computer aiding tools for the methods intended for investigating such relations for : deergonomicity of operators, defuncionality of machine processes, deecologicity of natural environment containing living objects and desozologicity expressing rate of wear in artificial environmental objects, i.e. working units of wind electric power plant and its surrounding.

There were :

- $\quad$ worked out and identified profits and outlays in lifecycle phases of wind electric power plant, giving relations as to the essence of index effectiveness,

- $\quad$ verified the methods for investigation and assessment of life - cycle destructiveness of working units of wind electric power plant .

There was numerically determined a level of life-cycle destructive impacts for a selected working unit with taking into account available models of post-service utilization ( waste dump, or recycling ).

From realization of the research tasks there were obtained the results confirming that in each case the lowest value of environmental load was associated with the utilization mode based on the recycling of raw materials, plastics and other materials, sub-units and units of offshore wind electric power plants ( up to $60 \%$ ).

The dominating area with regard to destructive load onto health of operator (-s), state of and changes in natural environment as well as technical infrastructure was the demand on energy (beginning from 3,5 up to almost $5 \mathrm{mln}$ MJ per life cycle - depending on a selected model) [12].

There was demonstrated that it is possible to more thoroughly recognize real life -cycle scenarios for working units of wind electric power plants as well as plastics and other materials and elements used for their building with special account taken for available models of post-service 
utilization. This makes it posible to conduct further research on and assessment of life-cycle phases of working units and the above mentioned materials and components of wind electric power plants on the basis of data coming not only from their producers but also users, moreover - to work out a constructive, more environment - friendly algorithm for managing the working units, materials and elements withdrawn from service.

It should be added that this work enriches knowledge in the area of the designing, constructing and operating of machines, devices and installations as well as processes of wind energy transformation, monitoring, useful operation aspects as well as effectiveness and functionality of large-power wind electric power plants. There was pointed out that to conduct further research on intelligent processes for wind energy mechanical transformation, is necessary. As assumed, the presented original, proposed by these authors, relations between destructiveness and profits, outlays and effectivenesses of operation of large wind power systems constitute an inspiration for widening understanding and a crucial phase for conducting further research in this field.

Based on the state-of-the art of current knowledge as well as the results of these authors' own research, it may concluded that application the wind electric power plants make it possible to really improve the ecological management of the world's energy resources towards obeying the principles of intelligent and sustainable development.

\section{BIBLIOGRAPHY}

4. Barlow, J.: Innovation and learning in complex offshore construction projects, Research Policy, 7-8, (2000), pp. 973-989.

5. Breton, S. P. i Moe, G.: Status, plans and technologies for offshore wind turbines. Renewable Energy. 34 (3), (2009). pp. 646-654

6. Chakrabarti, S.: Handbook of offshore engineering, Elsevier, Amsterdam 2005.

7. Crawford, R. H.: Life cycle energy and greenhouse emissions analysis of wind turbines and the effect of size on energy yield. Renewable and Sustainable Energy Reviews. 13 (9), (2009), pp. 2653-2660

8. Flizikowski J., Kruszelnicka W., Michałowski M., Szala G., Tomporowski A. : Bulkhead door - critical evacuation states. Polish Maritime Research, 24 (1), (2017), pp. 66-71.

9. Flizikowski J., Topoliński T., Opielak M., Tomporowski A., Mroziński A. : Research and analysis of operating characteristics of energetic biomass micronizer, Eksploat. i Niezaw. ( Mainten. Reliab.)17 (1), (2015), pp. 19-26
10. Flizikowski, J., Piasecka, I., Kruszelnicka, W., Tomporowski, A., Mroziński, A. : Destruction assessment of wind power plastics blade. Polimery, 63(5), (2018), pp. 55-60.

11. Flizikowski, J., Sadkiewicz, J., Tomporowski, A. : Functional characteristics of a six-roller mill for grainy or particle materials used in chemical and food industries. Przemysl Chemiczny, 94(1), (2015), pp. 69-75.

12. Garrett P., \& Rendc, K.: Life cycle assessment of wind power: comprehensive results from a state-of-the-art approach. The International Journal of Life Cycle Assessment, 18(1), (2013), pp. 37-48.

13. Gill, A.B. : Offshore renewable energy: ecological implications of generating electricity in the coastal zone, Journal of Applied Ecology, 4, (2005), pp. 605-615.

14. Haapala, K. R., Prempreeda, P. Comparative life cycle assessment of $2.0 \mathrm{MW}$ wind turbines. Int. J. Sustainable Manufacturing, 3 (2), (2014). pp.170-185

15. Kasner, R.: Assessment of benefits and investments for wind farm life cycle, Dissertation. Poznan: Poznan University of Technology (2016)

16. Kłos, Z., Lewicki, R., Koper, K. : Application of environmental characteristics of materials in sustainable development. In: I. Horvath, F. Mandorli, Z. Rusak (Ed.), Tools and methods of competitive engineering, Vol. 1-2 (pp. 1319-1320). Delft University of Technology, Delft 2010.

17. Kong, C., Bang, J., Sugiyama, Y. : Structural investigation of composite wind turbine blade considering various load cases and fatigue life. Energy. 30 (11), (2005), pp. 2101-2114

18. Kowalik, K., Sykut, B., Marczak, H., Opielak, M. : A method of evaluating energy consumption of the cutting process based on the example of hard cheese. Eksploatacja i Niezawodnosc (Maintenance and Reliability), 15(3), (2013), pp. 241-245.

19. Marczuk, A., Caban, J., Savinykh, P., Turubanov, N., Zyryanov, D. : Maintenance research of a horizontal ribbon mixer. Eksploatacja i Niezawodnosc (Maintenance and Reliability), 19(1), (2017), pp. 121-125.

20. Mattar, C., Guzmán-Ibarra, M. C. : A techno-economic assessment of offshore wind energy in Chile. Energy, 133, (2017), pp.191-205.

21. Mearns, K., Whitaker, S.M., Flin, R. : Safety climate, safety management practice and safety performance in offshore environments, Safety Science, 8, (2003), pp. 641-680.

22. Mroziński, A., Piasecka, I. : Selected aspects of building, operation and environmental impact of offshore wind 
power electric plants. Polish Maritime Research, 22(2), (2015), pp. 86-92.

23. Nguyen, Tuyet, T. A., Chou, S. : Maintenance strategy selection for improving cost-effectiveness of offshore wind systems. Energy Conversion and Management, 157, (2018), pp. 86-95.

24. Otremba Z., Andrulewicz E. : Physical fields during construction and operation of wind farms by example of Polish maritime areas, Polish Maritime Research, 21(4), (2014), pp.113-122.

25. Piecuch, T., Kowalczyk, A., Dąbrowski, T., Dąbrowski, J., Andriyevska, L. : Reduction of Odorous Noxiousness of Sewage Treatment Plant in Tychowo. Rocznik Ochrona Srodowiska, 17, (2015), pp. 646-663.

26. Rudnicki J. : Application issues of the semi-Markov reliability model, Polish Maritime Research, 22 (1), (2015), pp. 55-64.

27. Szyszlak-Barglowicz, J., Zajac, G., Slowik, T.: Hydrocarbon emissions during biomass combustion. Polish Journal of Environmental Studies, 24(3), (2015), pp.1349-1354.

28. Thomson, R. C., Harrison, G. P. Life Cycle Costs and Carbon Emissions of Offshore Wind Power. ClimateXChange, Edinburgh 2015

29. Tomporowski, A., Flizikowski, J, Kasner, R., Kruszelnicka, W. : Environmental control of wind power plant technology ( in Polish). Rocznik Ochrona Środowiska, 19, (2017), pp. 694-714.

30. Tomporowski, A., Flizikowski, J, Opielak, M., Kasner, R., Kruszelnicka, W. : Assessment of energy use and elimination of $\mathrm{CO}_{2}$ emissions in the life cycle of an offshore wind power plant farm. Polish Maritime Research, 24(4), (2017), pp. 93-101.

31. Yang, J.,Chang, Y.,Zhang, L.,Hao, Y., Yan, Q.,Wang, C. : The life-cycle energy and environmental emissions of a typical offshore wind farm in China. Journal of Cleaner Production. 80, (2018), pp. 316-324.

32. Zajac, G., Wegrzyn, A. : Analysis of work parameters changes of diesel engine powered with diesel fuel and FAEE blends. Eksploatacja i Niezawodnosc (Maintenance and Reliability), 2, (2008), pp. 17-24.

\section{CONTACT WITH THE AUTHORS}

Andrzej Tomporowski

e-mail:andrzej.tomporowski@utp.edu.pl

University of Technology and Science in Bydgoszcz Mechanical Engineering Faculty al. Prof. S. Kaliskiego 7

85-796 Bydgoszcz

Poland 